\title{
Newly Formed Words in the Novels of Ukrainian Science-Fiction Writers of the Second Half of the Twentieth Century
}

\author{
N. V. Leonova \\ National Metallurgical Academy of Ukraine, Dnipro, Ukraine \\ Corresponding author. E-mail: leonoffnatali@ukr.net
}

Paper received 25.10.18; Accepted for publication 02.11.18.

\begin{abstract}
https://doi.org/10.31174/SEND-Ph2018-182VI53-06
\end{abstract}
\begin{abstract}
The current article reports on the complex analysis of the neologisms specific character in the language of the Ukrainian science-fiction writers of the second half of the twentieth century. The semantic and the lexical groups of the neologisms are studied as one of the ways for the contemporary Ukrainian language to develop. Various ways of creating of authoring neologisms are also being researched.
\end{abstract} word.

Keywords: newly formed word, the language of the science-fiction writing of the XX century, neologisation, occasionalism, usual

Introduction. Taking into account the science fiction peculiarities, namely unreal situations, objects, characters, processes and their inadequacy with respect to the everyday life, it should be noted that the prevailing quantity of the newly formed words is based on English stems with specific Ukrainian way of derivation.

Occasionalisms and newly formed words within the science fiction writing are used by the authors for naming items, notions and processes from the world of their imagination. The characteristic feature of the authors' original manner is the individual approach to the means of the words formation. In cases when the author cannot select the proper word from the usual vocabulary to completely render the new notion he/she is developing it in the ambient of the science fiction writing. Further, this author creates the new lexical unit by conventional or nonconventional word-building models, which are peculiar to the own creative style. If newly formed lexical units are used properly, they enrich the standard language. The area where individual author's neologisms function is the literary style, the poetic genre and science-fiction genre.

Previous Publications Review. The studies of newlyformed words gain a considerable attention in the contemporary language science, particularly, the issues of the varieties and how they enlarge the contemporary Ukrainian language vocabulary.

Neologisms have always been in the focus of the linguists' interest. Thus, V. Kovalov (1983), N. Klymenko (2002) studied the word-building structures of the neologisms belonging to different parts of speech; I. Bilodid (1973) and O. Ponomariv (2000) devoted their works to the analysis of the semantic and stylistic potential of the new words.

Urgent Character of the Studies. With the current research we perform the comprehensive analysis of the principle processes of neologisation within the lexical material of the science fiction writing of 1970s-1990s.

We address the newly formed words of common language and those belonging to individual authors' styles. Their existence is determined by the linguistic, social, cultural and textual factors of their lexical groups.

The research aims at demonstrating the ways how the newly formed words and occasionalism characterize the processes of neologisation within the standard language of the second half of the XX century and at determining the set of the social and cultural factors as well as the au- thors' intentions within the process of new words creation.

In order to reach the outlined aim, the following tasks are to be fulfilled: to analyze the new words applied in the science-fiction prose of the above-indicated time period; to determine newly formed words of the general language and those of the individual authors' vocabulary as well as occasionalism; to distinguish the social and linguistic peculiarities which evidence clearly the picture of the neologisation tendencies of the second half of the XX century.

Research Materials and Research Methods. The ground for the research is the texts of fantastic and science-fiction writing. The meanings of the words and their origin have been checked with the contemporary definition dictionary.

In order to study the claimed materials the analytical method, the comparative methods and the methods of lexical analysis have been applied. The object of the current research is newly formed words in the contemporary standard language of XX century, the subject of the research is the specific character of the new words within the language of the science-fiction novels by the Ukrainian writers of the second period of XX century.

According to the definitions of the respected linguists, neologisms are the words (incorporating their discrete meanings) and expressions, which have appeared at the contemporary stage of the language development but belong to the passive vocabulary [12, p. 377]. Newly formed words and occasionalisms as the units conditioned by a certain situation are commonly out of the active vocabulary of a language.

O. Ponomariv, for instance, makes a note that the passive vocabulary consists of the words which are not within the active usage (neologisms) and of those going out of the lexicon and filling the level of the archaic words [11, p. 108].

A great number of occasionalisms, which allow the growth of the expressiveness of the text, are used by the science fiction writers and this stipulates the intensification process of enlarging the vocabulary of the contemporary Ukrainian standard language. The contemporary standard language saturation with newly formed words was a quite expected tendency under conditions of polylingual situation within the Ukraine of the XX century. Moreover, the adaptation of new words was supported by readers' knowledge of several languages and that the ma- 
jority of those readers used occasionally formed words of English stems, which actively entered into various everyday situations. Thus, O. S. Myrgorodska focuses the attention of the echoing reflections of the thereof tendency in the Ukrainian language in the first decade of the XXI century: “... lexical material with foreign elements is actively used by the students, young professionals, international company staff and regional television broadcasters".

Such tendencies are considered as related to the extralinguistic factors, among them could be named "opportunities to work seasonally oversees, work within Ukraine for international companies, where English is the language of an internal communication, work with franchising companies, from which technologies, brands and terminology are borrowed. The latter is added various affixes" [8, p. 90].

However, comparing against the situation with the poetry, where neologisms are the words with a pronouncedly distinguished emotional and expressive shades, it can be noted that the specific character of the science-fiction writing is that the neologisms are created by authors mainly with the purpose to name extraterrestrial objects, technology, social organisations, professions of the future or the imaginary reality; the science-fiction neologisms are commonly of terminological nature and their use allows authors to create the atmosphere of reality for the unreal events.

One of the distinguishing features of the latter mentioned neologisms is that despite the time period of their creation, they predominantly remain to be authoring and are not transferred into the usual vocabulary: “

As a rule, the authoring neologisms rarely enter the widely used vocabulary and are suitable only within certain texts, however some of them managed to enter the standard language. Thus, in particular, the words created by classical Ukrainian artists have strongly settled down in our language and entered its active vocabulary [in the Ukrainian language]" [4; p. 504], e.g.: words created by T. Shevchenko - vysokocholyi (vysok- +interfix -o-+chol+adjective suffix $)=$ Ukrainian equivalent for highbrowed); those by I. Nechui-Levytskyi - svitohliad (svit+ interfix -o-thliad= Ukrainian equivalent for overlook), samosvidomist (sam-+interfix -o-+svidomist = Ukrainian equivalent for self-identity); words by Lesia Ukrainka provesna (pro-+vesna = Ukrainian equivalent for early spring or spring beginning). The newly formed words by I. Asimov (robot, computer) are actively used in the contemporary world not only in science-fiction writing and by in the standard language. The words of usual vocabulary often enlarge their semantics in science-fiction writing and acquire the meanings of the newly formed technology terms, e.g.: "Avtomatychni videokamery vysotnoi kapsuly meteopatrulia, shcho ohliadaly prostory yevropeiskoi taihy ... (translation: Automatic closed circuits of high capsule of metheological patrol, that watch the spaces of European taiga...)"; "Koly lehkyi chervonyi Elf - riatuvalnyi kater P-7656 - spustyvsia na vodu ... (When light-weighed red Elf - rescue boat P-7656 was launched...)" [3; p. 12]; "Des tam u hlybyni neba... nad saviieiu plavav SP-6 - hihantskyi kosmoport dlia transhalaktychnykh zorelotiv (There, within the depth of the sky ... over Savia, was flying SP-6-giant cosmoport for transgalaxy astrofliers)." [2; p. 22]; “Khronohen henerator-initsiator reaktsii khronorozpadu "provalyvsia" v mynule na sotni milioniv a mozhe y na miliardy rokiv ... (Chrongen as a generator-initiator of chron decomposition reaction has fallen into the past as far as hundreds of millions of years or, maybe, milliards...)"; "Halaktychnyi kondensator informatsii yakyi my nazyvaly chornym papirusom ... (The Galaxy condenser of information, which we used to call Black Papyrus...)." [1; p. 23].

A widely spread technique of the contemporary Ukrainian writers of science-fiction is to use within the texts both individual authoring newly formed vocabulary and canonical one, and they function in harmony with usual lexical items, adjecting them and making them more effective, e.g.: "Hnat Romashyn ocholiuvav viddil bezpeky naukovykh doslidzhen Upravlinnia avariinoriatuvalnoi sluzhby zemli - sluzhba odna ale rizni napriamky ... (translation: Hnat Romashyn headed the scientific researches security department of Earth Planet Emergency-Rescue Service Administration - the same administration but different directions)."; “...vidkorkovuvaly pliashky, zahotovleni shche na zemli, $i$ rozkhliupuvaly vyno, ..., na hihiienichnyi psevdo parket...(...opened the bottles procured on the Earth planet and spell the wine... on hygienic pseudo-parquet floor)" [3; p. 43]; "Yulis skriz vozyv z soboiu kinoteku, zalyshenu saviianam ekipazhem Serpa dlia znaiomstva $z$ zemnym svitom (Everywhere Yulis brought with him the record library, left to Saviians by the crew of Serp in order to introduce the terrestrial world to them)." [2; p. 45]; "Budynok laboratorii Chasu bilia bashty pryskoriuvacha utsiliv, ale mav dyvnyi vyhliad ...(The building of Time Laboratory, near the tower of the accelerator, escaped destruction but had a strange view...)"; "Ni fotona ni zvu$k u$...tak, ni slovechka ne pronykaie z tiiei hravitatsiinoi pastky...(Neither photon nor sound... so no word penetrate out from this gravitation trap...)" [1; p. 43]

Newly formed words, wherein synthetically are united the features of the traditional word-building and the specific features of an author's world-building style, also have an influence of the text stylistics. Rather original from this standpoint are eoccasionals, newly formed names of social organisations, social services, scientific institutions, which can be found in the texts of science fiction writing, e.g.: "Rozsliduvannia, provedene ... vchenymy Akademii nauk Zemli (translation: The investigation conducted ... by the scientists of Academy of Sciences of the Earth Planet)"; "Koly mohutnii korabel Violy ... z emblemamy Riatuvalnoi Sluzhby Flotu ... pidchepyv ... (When the mighty ship of Viola ... with emblems of Fleet Rescue Service ... picked up ... )" [3; p. 32]; "Do rechi, za nashoiu robotoiu pylno stezhyv SEKON (Viddil sotsialnoho $i$ etychnoho kontroliu za nebezpechnymy vyprobuvanniamy) (translation: By the way, our activities are carefully monitored by SEMUN Department of Social and Ethical Monitoring of Hazardous Tests)"; "Vytiah z dopovidi stariishyn Korporatsii Ksenobiolohiv Koordynatsiinoi Rady Zemli ...(Extraction from the Report of the senior representative of Xenobiologist Corporation of Coordination Council of Earth Planet...)" [3; p. 56]. Such newly formed units add the official colouring into the text and this acts as an 
adjunct to the demand of serious attitude, that is a kind of impact on the reader's emotional perception.

Further, the semantic shifts which usually occur within the words of this type allow them to generate the new phraseological links with other words and this, in its turn, permits the writers to create new structural and semantic units with the word being reconsidered. As instances can serve the following: standartnyi kvark-keson (translation: standard quark-caisson); pilot-riatuvalnyk Koordynatsiinoi Sluzhby Flotu (pilot-rescuer of Fleet Coordinating Service) [3; p. 14]; inzhener-khronomekhanik (engineer chronotechnician).

One more way of enlarging the vocabulary within the language of writing is quite frequently taken by science fiction writers: it is lexical borrowing from other languages. Following this tendency, the writer can operate with one or with several stems originated from the languages different from that of Ukrainian and create compound nouns as given (their word-building patterns are shown after equals): taimfah $=$ time + phage $;$ hravikhid $=$ gravit-+hid (Ukrainian equivalent for pace) [3; p. 22]; transhalaktychnyi $=$ trans- $+\gamma \alpha \dot{\lambda} \alpha$-+adjective suffix+ending [2; p. 17]; khronopryskoriuvach = abbreviated chronos + pryskoriuvach (Ukrainian equivalent for accel-

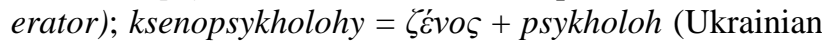
equivalent for psychologist ( $\psi v \chi \eta ́ ~+\lambda o ́ \gamma o \varsigma)+$ Ukrainian plural noun ending $[3 ;$ p. 15]; neirohraf $=$ abbreviated

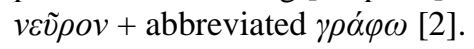

Research Results and Discussion. Newly formed words created by the authors of science fiction writing or authoring newly formed words are the source of speech innovation, they are designed to perform esthetic function. The functions of authoring neologisms always depend on the aim of the author's pursuit. The usage of innovations in science-fiction texts is very often propelled by the author's desire to convey the ideas concerning the certain issue as precise as it is possible. The authoring newly formed words often describe various aspect of attitudes of the subject's speech to the object. Such newly formed words due to their means of expressiveness are capable of reflecting the inner world and feelings of the personality that is the subject of the speaking act. The expressiveness is achieved through the impressional reinterpretation of the word's meaning implemented by affixation and stem-composition.

The extraordinary character of the occasionalism is related to the unusual way how these speech units have been created. Considering the formation of individual authoring expressive neologisms within the Ukrainian language, one should be remind of a word-building means such as the usage of innovative suffices -yshche, -ysko with the purpose to identify the huge sizes of the objects, astronomic notions, etc. In the area of the science-fiction writing these objects and notions are permitted to act as the real creatures do, e.g.:"“...navit nash dim u tsii ekspedytsii - nash zorelotyshche ne vytrymav by ... (translation:... even our house in this expedition - our huge starship would not withstand...)"[3; p. 68]); "Take sobi psevdohalaktyshche linyvo rozkynulosia na bahato parsekiv ... (Existing on its own way, huge pseudogalaxy lazily spreads for many parsecs)" [2]; "Volovyi zariad zibranyi Violoiu ... nyshchivno rukhnuv na biomonstrysko ...(The charge of will, gathered by Viola ...destructively rushed on the huge biomonster...)" [3; p. 49].

There is no modern language still being developed in a static state since the lexicon, according to V. M. Rusanivskiy, is the organism in which the new cells are being born while the old ones are dying and the life cycle is supported by introduction of nutrients from outside while the process of interchange between all its parts constantly occurs $[14$, p. 46]. These words of the renown linguist are very consistent to characterize the neologisms which perform the function of the "blood donor" within the lexical system of the language. The contemporary authoring derivative process with occasionalism and newly-formed word creation are both characterized by combining new unexpected ideas with attracting the traditional approach. This is considerably encouraged by extralinguistic factors of historic development of the Ukrainian territory and the Ukrainian language, hence the social and cultural conditions always play the role of the grounds for neologism creation in any period of the standard language development.

Furthermore, we see the opportunities for expanding the expressiveness within the innovations in the sphere of compound words. The writers of science fiction incorporate in one word the irreconcilable parts. That is a characteristic feature for the individual author's approach to the creation of new original compound units of speech, between which unexpected paradox links appear by the will of the author and these links are between the realities of modern life or between the notions semantically far from each other. The newly formed words of this type grow into local images, which do not contradict with an author's idea how the unreal or imaginary object should be depicted, e.g.: “...biomashyna naivyshchoi skladnosti zhyva mysliacha ... (translation:...biomachine of the highest complexity, it is alive and intelligent)" [3; p. 70]; "Rano chy pizno antykantseryn my znaidemo (Sooner or later anticancérine will be found)" [2; p. 44]; “...Vcheni stvoryly teoriiu khronoprokolu abo yakshcho khochete "burinnia chasu" (The scientists have developed the theory of chronpiercing or if you like it more in other words "drilling of time")"; "Vohnesmikh dyvyvsia na noho prymruzhyvshy ochi ... (Firelaughter was looking at him with the eyes partly closed" [1; p. 34]. Thus, individually authoring neologisms are produced by various means, in particular, as follows:

- by stem composition, e.g.: khronopryskoriuvach (abbreviated chronos + interfix -o-+ Ukrainian equivalent for accelerator); fluoropanel (Ukrainian equivalent for fluorine + interfix -o-+ Ukrainian equivalent for panel) [3; p. 25], statotron (start +interfix -o-+ equivalent for holder) [2];

- by word composition, e.g.: Lon-Heia (LosneGaia) [2], Balor-Deviat (Balor-nine), kolehykhronofizyky (colleages chronos physical scientists) [3; p. 23].

Among authoring occasionalisms, we can find a few cases of formation by the lexical and semantic means, e.g.: konkistadory (conquistadors), kosmichni yaitsia (cosmic eggs), chumatski shliakhy (milky ways).

This way of formation is productive, interesting and specific for the individual authoring word formation and expands the science fiction area. In order to enhance the 
emotional colouring within texts, the authors combine those components which are different by their semantics. Such kind of paradoxic union is stipulated by the associations of the author's perception of the world.

Among the occasionalisms within the frame of compound word-building structures, there can be found two components joint together by means of external similarity or internal functional condition, e.g.: "Za kreiserombiomashynoiu slid stezhyty ne $z$ poverkhni planety ... (translation: The biomachine-cruiser should be followed not from the surface of the planet ...)" [3; p. 34]; "Nulvyklyk pryiniatyi des o vosmii ... (Zero-call accepted at around eight...)"; "Kub peretvoryvsia na paukakonkiskadora (The cube turned into the spiderconquistador)". There are authoring newly formed words which can be distinguished into a separate group, they are the proper names of secret organisations and security degree codes for a situation, e.g.: "Dva roky tomu ya buv svidkom tryvohy za formoiu "Shtorm", todi Upravlinnia provodylo operatsiiu "Demon" (translation: Two years ago I experienced how the Storm format alarm set off, at that time the Secret Intelligence Service was conducting the Demon operation)"; "Sektor "Delta", kub 6347, zirka Krystofovycha-Korniaku, riativnyi kater tsentr-699 (Sector Delta, cube 6347, Krystofovych-Korniak star, center-699 rescue vehicle)" [3; p. 73]; "Era Velykykh $\boldsymbol{i}$ Mohutnikh Sprav, - proburmotiv susid ... ("The Era of Great and Mighty Deeds", the neighbour mumbled ...)".
The results of the reported research have been discussed at the scientific seminars of History and Ukrainian Studies of NMetAU.

Conclusions. Based on the structural and semantic properties of the authoring neologisms, they can be classified into the groups of lexical neologisms and semantic neologisms. The items of both groups could be expressed by one word (one root word, compound or acronym) or by lexicalized union of several words. The unexpected combinations within the words illustrate the individual authoring occasionalisms which are in every case the result of the author's creative work made with the text material and its imagery. The neologisms within the works of science-fiction writing attract special attention with its unique and paradoxical character.

The analysis on the literature of the second half of the $\mathrm{XX}$ century supports the idea of revealing the specific character for this period of neologisation: the processes of lexical material borrowing generally along with the spontaneous and active indirect use of new lexical material coming from the English language were the means expanding the opportunities of the authoring neology development, however, they are the authoring neologisms which are the lexical material mostly often being left behind the active vocabulary but existing as the newly formed words only within the texts to which they belong.
1. Berdnyk O. P. Chasha Amrity. / O. P. Berdnyk - K.: Dnipro, 1989. $-270 \mathrm{p}$.

2. Burlai V. Z. Zalata L D. Ushchelyna Synikh Tumaniv. / V. Z. Burlai, L. D. Zalata - Dnipropetrovsk : Promin, 1969. $101 \mathrm{p}$.

3. Dmytruk A. V. Aurentyna. / A. V. Dmytruk - K.: Veselka, 1982. - $142 \mathrm{p}$.

4. Hromiak R. T. Literaturoznavchyi slovnyk-dovidnyk / R. T. Hromiak, Yu. I. Kovaliva, V. I. Teramka. - K. : Akademiia, 2007. $-504 \mathrm{p}$.

5. Klymenko N. F. Neolohizmy u riznykh styliakh suchasnoi ukrainskoi ta novohretskoi mov / N. F. Klymenko // Problemy semantyky slova rechennia ta tekstu zbirnyk naukovykh statei. - K., 2002. - Vyp. 8. - P. 388-394.

6. Koloiz Zh. V. Ukrainska okazionalna deryvatsiia Zh. V. Koloiz. - K. : Aktsent, 2007. - 311 p.

7. Kovalov V. P. Slovotvir Khudozhnikh Neolohizmiv / V. P. Kovalov // Ukrainska mova i literatura v shkoli. - 1983. - № 6. - P. 25-29.

8. Myrgorodska O.S. Perevod kak sredstvo formyrovanyia yazykovoi kultury professyonalno-tekhnycheskoi elyty // Rol

\section{RENCES}

humanytarnoho obrazovanyia $\mathrm{v}$ formyrovanyy professyonalno-tekhnycheskoi elyty. - Dnepropetrovsk: 2007 - P. 89-90.

9. Ocherky leksykohrafyy yazyka pysatelia. - L.: Yzd-vo unyversyteta, 1981. $-160 \mathrm{p}$.

10. Onomastyka i apeliatyvy zb. nauk. prats. / za red. V. O. Horpynycha. Vyp. 8,- Dnipropetrovsk: Vyd-vo DNU, 1999. - 142 p.

11. Ponomariv O. D. Stylistyka suchasnoi ukrainskoi literaturnoi movy: pidr. dlia stud. humanit. spets. / O. Ponomariv. - Ternopil: Navchalna knyha - Bohdan, 2000. - 248 p.

12. Ponomariv O. D. Suchasna ukrainska mova: pidruchnyk / O. Ponomariv, V. V. Rizun, L. Yu. Shevchenko ta in. ; za red. o. d. ponomareva. - 4-te vydannia.- K. : Lybid, 2008. $488 \mathrm{p}$.

13. Suchasna ukrainska literaturna mova. Leksyka i frazeolohiia. Za Red. I.K. Bilodida, - K. : Naukova dumka, 1973. - 439 p.

14. Ukrainska mova: entsyklopediia / V. M. Rusanivskyi, O. O. Taranenko. - K. : Prosvita, 2000. -377 p.

15. Vynohradova V. N. Stylystycheskye Sredstva Slovoobrazovanyia. V kn..: Stylystycheskye yssledovanyia. - M. : Nauka, 1972. $-276 \mathrm{p}$. 